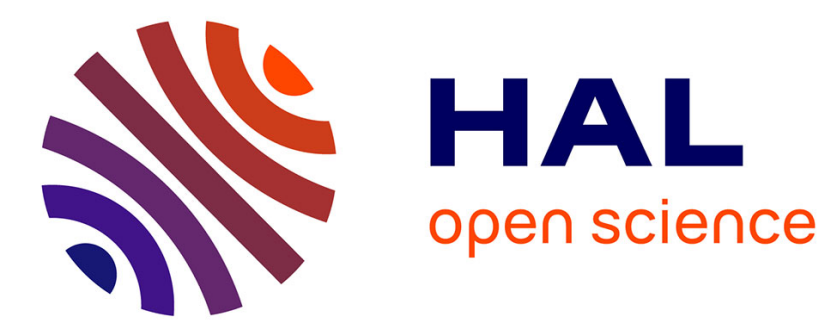

\title{
Pelvic and neonatal size correlations in light of evolutionary hypotheses
}

Pierre Frémondière, Lionel Thollon, François Marchal

\section{To cite this version:}

Pierre Frémondière, Lionel Thollon, François Marchal. Pelvic and neonatal size correlations in light of evolutionary hypotheses. American Journal of Human Biology, 2021, 10.1002/ajhb.23619 . hal03443032

\section{HAL Id: hal-03443032 \\ https://hal.science/hal-03443032}

Submitted on 23 Nov 2021

HAL is a multi-disciplinary open access archive for the deposit and dissemination of scientific research documents, whether they are published or not. The documents may come from teaching and research institutions in France or abroad, or from public or private research centers.
L'archive ouverte pluridisciplinaire HAL, est destinée au dépôt et à la diffusion de documents scientifiques de niveau recherche, publiés ou non, émanant des établissements d'enseignement et de recherche français ou étrangers, des laboratoires publics ou privés. 
"This is the pre-peer reviewed version of the following article: " Pelvic and neonatal size correlations in light of evolutionary hypotheses", which has been published in final form at https://onlinelibrary.wiley.com/doi/abs/10.1002/ajhb.23619. This article may be used for noncommercial purposes in accordance with Wiley Terms and Conditions for Use of Self-Archived Versions.

Is there a remnant signature of obstetric dilemma in modern pregnant women?

Frémondière Pierre, PhD*1,2, Thollon Lionel PhD 3, Marchal François PhD 2.

1 Aix Marseille Univ, School of Midwifery, Faculty of Medical and Paramedical Sciences, Marseille, France

2 Aix Marseille Univ, CNRS, EFS, ADES, Marseille, France

3 Applied Biomechanics Laboratory (UMR-T24), Marseille, France

*Corresponding author : Pierre Frémondière

Contact adress : EU3M Medicine University North department, Boulevard Pierre Dramard, 13015 Marseille (France)

Contact phone : +33491698792

Email : pierre.fremondiere@univ-amu.fr

Running title: obstetric dilemma in modern women

Keyword: fetal-pelvic disproportion, adaptation, birth canal, fetal growth, gestation.

Abstract

Objective: The aim of this study was to analyse the correlations between maternal size, neonatal size, the dimensions of the maternal pelvis and gestational variables.

Methods: In this study 131 mother-infant pairs were recruited. We investigate correlation between maternal traits (height, BMI, uterus height), neonatal traits (gestational age, birthweight, head, suboccipito-brematic and abdominal girth) and pelvic variables (conjugate diameter, inter-spinous diameter, sub-pubic angle) collected from computed tomography pelvimetry.

Results: We found that the five neonatal traits are significantly inter-correlated. Among maternal traits, height is highly correlated with conjugate and inter-spinous diameters. Subpubic angle is correlated with inter-spinous diameter. Uterus height is correlated with the four neonatal growth traits. Gestational age is correlated with birthweight, head and abdominal girth. Among neonatal and pelvimetry correlations, conjugate diameter is highly correlated with suboccipito-bregmatic girth.

Discussion: Matches between gestational age and neonatal traits, and between uterus height and neonatal traits could be related to the process of fetal maturation, orchestrated by the pregnancy clocks. Indeed, the triggering of parturition is supposed to result from the coordination and initiation 
of 4 clocks (endocrine, fetal membrane, decidual and myometrial) implying fetal organ maturation and fetal membrane senescence. Obstetric dilemma is an evolutionary tradeoff resulting from the conflicting pressures between bipedal locomotion efficiency and the selection for bigger brain size at birth. Correlation between suboccipito-bregmatic girth and conjugate suggests that the more the inlet is sagitally reduced, the smaller suboccipito-bregmatic girth is. Moreover, acquisition of the adult birth canal morphology causes minimal variation at the inlet, compare to the fetus morphology, suggesting that suboccipito-bregmatic girth follows the size of the inlet, but in one-way. Therefore, our interpretation of this pelvic-fetal correlation suggests that the pelvic size seems to be also a constraint to the fetal growth process. This adjustement of fetus size to the birth canal dimensions limits the risk of dystocia and could be interpretated as a remnant signature of the obstetric dilemma in our obstetrical sample.

\section{Introduction}

The physiology of birth process, timing of the pregnancy or the mechanism of fetal growth process remain unclear in many aspects. Among these aspects, the relationship between pelvic size, birthweight, and pregnancy length has been the source of many discussions. Most authors widely assumed that modern human birth has been shaped by evolutionary stresses (Washburn, 1960; Berge et al. 1984; Häusler and Schmid, 1995; Rosenberg and Trevathan, 1996; 2002; Trevathan, 2011; Lovejoy, 2005; Wells, 2009), such as bipedal locomotion (Berge et al. 1984; Rosenberg and Trevathan, 1996; 2002), ecological stresses (Wells, 2009), genetic drift (Betti et al., 2014; Betti and Manica, 2018), thermal environment (Weaver and Hublin, 2009; Betti et al., 2014), or encephalization (Tague and Lovejoy, 1986; Häusler and Schmid, 1995; DeSilva and Lesnik, 2008). When compared with others hominoid, the patterns of modern human birth are markedly distinct (Berge et al., 1984; Tague and Lovejoy, 1986; Franciscus, 2009). These evolutionary stresses are supposed to generate a complex parturition in modern human: a higher risk of difficult labor i.e. dystocic labor (Wittman and Wall, 2007; Franciscus, 2009), and a complex and lengthy way to give birth vaginally with the emergence of obstetrical mechanism (Malinas and Favier, 1979; Frémondière et al. 2017), which includes rotational birth. For this reason, some authors suggested that human neonate shows specific neurological and growth patterns (Martin, 2007). Indeed, human infant is supposed to be unusually dependent for the first year of life (Martin, 2007). According to this observation, Portmann (1941) suggests that human embryonic development lasts 21 months and is divided in two periods: intrauterine (9 months) and extrauterine (12 months). As a result human neonate retains fetal pattern of brain growth when delivered (Washburn, 1960). When considering several eutherian species, brain growth rate during fetal development is conserved, and humans share brain growth patterns with other eutherian species. For example, they are born after the peak of brain growth acceleration, as well as macaques, marmosets, guinea pigs, sheeps, pigs and oxen (Hallen et al., 2017). But primates (Hallen et al., 2017) and more specifically humans (Martin, 2007) exhibits slow rates of body growth that increases brain size/body size ratio (encephalization) in utero. 
After birth, subsantial brain growth relative to body growth continues in humans but not in others primates where a switch in brain growth relative to body growth occurs (Martin, 2007). Slowing postcranial growth could be an adaptation for reallocating ressources to sustain brain development (Martin, 2007; Hallen et al., 2017). For the neonate, this implies a unique aspect of brain growth sharing precocial and altricial characteristics. As precocial species, humans have an extended gestational period, a large adult brain size, and usually give birth to a single offspring whereas they have a small neonate/adult brain size ratio and a helpness newborn typical to altricial species. This unique mosaïc of neonate patterns is referred to as "secondary altriciality" (Portmann, 1969; Coqueugniot and Hublin, 2007). For parents, this requires a higher investment, which has cultural and biological consequences: the task of child care could be supported by other members of the family (Bogin, 1997), and the mother's milk is also design for sustaining a rapid brain growth during the infancy (Hinde and Milligan, 2011).

Evolutionary tradeoffs reflect necessary compromises among competing biological functions. For the reproductive function, Washburn (1960) uses the term "dilemma" to point out the tradeoff between bipedal demands and the selection for larger brains. Some authors suggest that the pelvic size is a critical factor that adjusts the brain size at birth to limit the risk of fetal-pelvic disproportion (Leutenegger, 1972; Häusler and Schmid, 1995; Frémondière et al., 2017; Wells et al., 2017). For others, the pelvic size plays a minor role and the fetal growth arrest is due to metabolic limitations (Dunworth et al., 2012). The "obstetric dilemma" refers to a hypothesis with several limitations that inevitably has weak assumptions. For example, humans have absolutely long gestation, large bodysize and brain at birth compare to non-human primates (Kuzawa, 1998; Dunsworth, 2018). Moreover, human is not the only primate that exhibits a tight fit between pelvis and fetal size (Dunsworth, 2018). Small bodied primates usually show a tight fit (Leutenegger, 1979) and among them, squirrel monkey or marmoset have often smaller sagittal dimension of the maternal pelvis than the length of the neonatal cranium (Leutenegger, 1982; Rosenberg, 1992). Moreover, the transversally wider female pelvises are as efficient as male pelvises concerning the locomotor performance (Warrener et al., 2015). However, bipedalism and erected posture are supposed to deeply reshape the birth canal. Figure 1 summerises these changes according to the comparative anatomy between humans and non-human primates. There are strong evidences that bipedalism has indirect consequences on the human birth process. However, its influences about the timing of parturition are still unclear. From a recent work analyzing the correlation between body size, pelvic and neonatal traits, Wells et al. (2017) suggest that pelvic dimensions are better predictors of neonatal size rather than nutritional status. This analysis of the correlations between maternal and neonatal traits is a reliable and innovative approach to understand how selective pressure impact fetal growth patterns. However, this work suffers from two limitations: the consideration of the head girth which does not correspond to the relevant cross-sectional area in human birth, and the use of clinic pelvimetry, i.e. external pelvimetric measurements, where variables are only proxy variables of the birth canal. The aims of this study are two-fold: first to investigate whether pelvic dimensions of the mother predicted birth size of the offspring, with the consideration of nutritional status and maternal height, but also with variables of the birth canal measured from computed tomography pelvimetry, and obstetrically relevant neonatal variables. We hypothesize that pelvic dimensions predict obstetrically relevant neonatal variables. These associations would reduce the risk of fetalpelvic disproportion, and represent a remnant signature of obstetric dilemma in our sample. Second, 
we want to check if uterus size mediates a potential correlation between pelvic traits and size of the offspring.

\section{Materials and Methods}

One hundred and thirty-one (131) women at Saint Joseph Hospital, March 29, 2011 to December 10, 2013 Marseille, France, were included in this single center study. The women were recruited from 10597 deliveries in the hospital. Inclusion critera were birth at term with a fetus in cephalic presentation and computed tomography pelvimetry prior to labor. Exclusion criteria were maternal pre-eclampsia, twin pregnancies, caesarean deliveries performed in case of abnormal fetal heart rate, or before 2 hours of arrest of labor, in case of abnormal uterine contraction or iterative caesarean delivery. Newborns were also excluded if they had congenital infections, malformations or genetic syndromes. All the 131 women had epidural anesthesia during labor. The center has three protocols for the pelvic scanning based on patient adiposity: low $(100 \mathrm{kV}, 25 \mathrm{~mA})$; standard $(100 \mathrm{kV}, 35$ $\mathrm{mA})$ and high adiposity $(120 \mathrm{kV}, 35 \mathrm{~mA})$. These three protocols produce low level irradiation ranging from $15 \mathrm{mGy} / \mathrm{cm}$ to $35 \mathrm{mGy} / \mathrm{cm}$. Indications for computed tomography pelvimetry were scar at uterus, breech presentation (during the pelviscan but cephalic presentation at the beginning of labor), suspicion or history of fetal-pelvic disproportion. Computed tomography pelvimetry was performed with a 16 Siemens Definition Flash strips scanner located in the Medical Imaging Department of the hospital. Intersection gap was 0.6-1 mm. Pelvises were reconstructed and measured using Amira 5.0.0 software (FEI Visualization Sciences Group / Zuse Institute Berlin). The three pelvic variables were the conjugate, interspinous diameters and the sub-pubic angle (figure 1). The newborn measurements were performed during the postpartum period using anthropometric tools (cephalometric compass, tape measure, newborn scale). Newborn measurements were birthweight, head girth, suboccipitobregmatic girth, abdominal girth (figure 1). The same operator (PF) measured all the pelvises and newborns. Suboccipito-bregmatic girth is a relevant obstetrical variable since it correspond to the presenting dimensions of the well-flexed head. Since flexion is a cardinal movement of labor (Walrath, 2003), well-flexed presentation represents the most common presentation in human birth (Malinas and Favier, 1979). Maternal age (years) and gestational age (weeks) were recorded. Maternal weight and height were measured and Body Mass Index (BMI, $\mathrm{kg} / \mathrm{m} 2$ ) calculated. Uterus height was measured with a plastic tape measure from the symphysis to the uterus fundus at the onset of labor. This study was approved by the South Mediterranean II Ethical Committee for Protection of Persons (1d-RCB 2011-A00072-39) and written informed consent was obtained from all the participants. Correlation analyses were performed with SPSS Statistics 17.0. A correlation was significant with a $p$-value $<0,05$. For statistics, we followed the method described in Wells et al. (2017). 1) Crude associations between maternal and neonatal traits were investigated. 2) Potential confounding effects of birth order and offspring sex in maternal and neonatal traits association were tested by ANOVA with birth order models correcting for multiple comparisons using the Bonferroni method. 3) Associations of maternal body size and BMI with neonatal traits were tested with multiple regression models. 4) To test if pelvic dimensions mediated these associations, we first added single pelvic dimension in the models, then we included all three pelvic dimensions and uterus height. 5) Associations of pelvic traits and uterus height with birthweight, and mediation of head girth in these associations were tested in additional models. All models were adjusted where relevant for offspring sex and birth order.

Results 
The table 1 shows the descriptive analysis of the sample of the 131 mother-infant pairs. The mean maternal age is 31.9 years, ranging from 22 to 42 years. At the beginning of the pregnancy, the mean weight is $64.1 \mathrm{~kg}$, ranging from 40 to $142 \mathrm{~kg}$., the mean neonate weight at birth is $3433 \mathrm{~g}$, ranging from 2300 to $4600 \mathrm{~g}$. There are 62 male and 69 female infants. Twenty seven mothers are primipara, 97 are $2^{\text {nd }}$ para and 7 are thirdpara or more. Table 2 shows crude correlations between maternal and neonatal traits. Among neonatal traits, the three neonatal variables are significantly inter-correlated with coefficients between 0,45 and 0,77 . Among maternal traits, height is highly correlated with conjugate and inter-spinous diameters $(r=0,424$ and 0,299$)$. Subpubic angle is correlated with interspinous diameter $(r=0,591)$. Among neonatal and pelvimetry correlations, conjugate diameter is highly correlated with suboccipito-bregmatic girth $(r=0,235)$. Uterus height is correlated with BMI $(r=0,387)$ and all the four neonatal traits $(r=0,394-0,403)$.

There is no significant association by ANOVA of birth order or offspring sex with maternal height or pelvic measurements. Concerning neonatal traits, there is no significant association of birth order or offspring sex with gestational age, birthweight or abdominal girth. Primiparas have a $1,5 \mathrm{~cm}$ higher uterus height compared to secondparas $(95 \% \mathrm{Cl} 0,2-2,7)$. Female infants have a 7,5 mm larger head girth (95\% Cl 1,5-13,5), and a $7 \mathrm{~mm}$ larger suboccipito-bregmatic girth (95\% $\mathrm{Cl} 0,4-13,6)$ compared to male infants. Then, offspring sex and order are considered in subsequent regression models.

Table 3 provides multiple regression models for the prediction of neonatal size with maternal nutritional statut and pelvic measurements. When adjusted for birth order and infant sex, gestational age is a predictor of all neonatal traits but not the suboccipito-bregmatic girth. These associations remain when uterus height alone or all maternal traits are added to the model. Among pelvic measurements, conjugate diameter is a predictor of head girth and suboccipito-bregmatic girth. In the combined model, conjugate remains independent predictor of suboccipito-bregmatic girth. Among maternal traits, uterus height is significantly associated with neonatal traits in simple and combined models.

Table 4 shows additional multiple regression models, testing whether associations of maternal pelvic dimensions with birth weight are mediated by maternal height or neonatal head girth. Maternal height is a predictor of birthweight in simple models, but these associations disappear after adjusting for neonatal head girth. Uterus height remains significantly associated with birthweight in simple and combined models.

\section{Discussion}

Conjugate diameter represents the antero-posterior enlargment of the pelvic inlet. According to Schaal and Riethmuller (2007), the inlet is a rigid bony ring where the effect of pelvic relaxation is minimal. The inter-spinous diameter corresponds to the midplane breadth whereas the subpubic angle represents the anterior space of the outlet. Contrary to the inlet, dimensions of midplane and outlet can increase during the birth process thanks to the backward displacement of the $5^{\text {th }}$ sacral vertebra with nutation and counternutation movements (Borell and Fernström, 1957a). Therefore, these latter two pelvic planes are not as critical during the fetal head descent than the inlet level. These different obstetric significances should explain the close relationship between the conjugate diameter and the suboccipito-bregmatic girth. Moreover, the suboccipito-bregmatic girth represents the circumference of a cross-section of the well-flexed presentation, which is the most common presentation in eutocic deliveries, while it enters the birth canal. It thus closely reflects the size of the 
presenting part at the inlet level. This may explains why correlation between conjugate diameter and head girth is absent in this work since head girth rarely represents the size of the presenting part (i.e. in case of deflexed presentation).

According to Wells et al. (2017), we do not find correlation between BMI of the mother and the rest of the neonatale variables. The nutritional status seems to be a weak predictor of neonatal traits. We find correlations between maternal height and maternal pelvic size. Previous studies demonstrate the allometric relationship between the pelvic size and other anthropometric measures among females (Holland et al., 1982; Ruff et al. 1997; Tague, 2000). This relationship may explain the dystocic outcome for women less than $1,60 \mathrm{~m}$ (Mahmood, 1988). Stature is positively correlated with the size of the inlet (Holland et al., 1982; Tague, 2000). Bi-iliac breadth is used as a proxy of body mass (Ruff et al., 1997). However, the correlation between stature and pelvic size could be different depending on the variable considered. In accordance with Holland et al. (1982), we find a positive association between maternal height and bispinous diameter. Conjugate is positively correlated with maternal height, but also with femoral length, used as a proxy of stature, and not with femoral head diameter, a proxy of weight (Tague, 2000). Moreover, subpubic angle is not correlated with BMI or height, and the percentage of variance of this variable is independent of body size (Tague, 2000). Correlation between maternal height and birthweight, but not BMI, may reflects a selection on fetal growth adaptation to maternal phenotype rather than external ecological conditions (Wells et al., 2017). The maternal height and conjugate diameter are highly correlated, as well as the sub-occipitobregmatic girth and conjugate diameter. Our findings suggest that the inlet size may drive the fetal growth process to adjust the birthweight to the size of birth canal. This process may reduce the risk of fetal-pelvic disproportion, increases the chance of mother-infant survival rate in a non-medicalized context, and appears to be a strong selection force as suggest by Wells et al. (2017). However, the mechanism explaining the limitation of the fetal growth process is still unclear. Dunsworth et al. (2012) suggest that the limitation from the maternal metabolism is the primary constraint of fetal growth. But this hypothesis does not explain the correlation between the pelvis and the fetal size. The metabolic hypothesis could be a consequence of a physical process that induces the onset of labor and limits the gestation length and the fetal growth. In this work we consider the symphyseal fundal height, a proxy of uterus size. As well, the uterus height is highly correlated with birthweight since it is used to assess the risk of intrauterine growth restriction in modern obstetrics practice (Ducarme et al. 2012). However, we do not find a correlation between the pelvic and uterus size. Our work brings new highlights in the complex relationship between gestational age, fetal size, uterus size and pelvic dimensions.

According to the obstetric dilemma hypothesis, pelvic dimensions and fetal size have to be strongly correlated since birthweight is a predictor of neonate mortality (Kramer, 1987). Pelvic dimensions would act as a " bottleneck » that restricts birthweight and neonatal size with a mechanism of downregulation: the smaller the pelvis, the smaller the neonate. This mechanism would be a crucial solution to protect the mother and her offspring from the risk of obstructed labor (Krogman, 1951; Washburn,1960; Schultz, 1969; Rosenberg, 1992; Rosenberg andTrevathan, 1996; Wittman and Wall, 2007; Walsh, 2008;Franciscus, 2009; Trevathan, 2011). Yet, the relationship between pelvic dimensions and neonate size could be more complex than previously described in the obstetric dilemma hypothesis. Pelvic dimensions partially predict neonatal dimensions in clinical practice (Ferguson et al. 1998). In this study, we investigate crude correlations among maternal and neonatal traits. We find that neonatal dimensions are strongly predicted by gestational age and uterus height. 
According to Fournié et al. (2007), uterus height and gestational age are correlated since uterus height (minus $4,3,2,1 \mathrm{~cm}$ or plus $1 \mathrm{~cm}$ ) is equal to the gestational age (in weeks of amenorrhea). This correlation helps clinicians to predict fetal growth retardation or abnormality in amniotic fluid volume. Gestational age and neonatal traits are correlated because the timing of human parturition stops the growth process at a specific age of maturation. The volume of the gravid uterus increases during the pregnancy until it reaches a critical size where parturition is induced (Menon et al. 2016). However, uterus height and gestational age are not correlated in this study. Two main causes could explain this result: 1) symphyseal-fundus height cannot reliably estimate the volume of the gravid uterus, or 2) gestational age, in a broad sense the timing of parturition, is independent of maternal traits and is the only independent factor explaining the neonatal size. The reproducibility of symphyseal-fundus height was investigated in few studies: the interobserver coefficient of variation is $6.4 \%$ but the sample sizes are small (two groups of 6 patients) (Calvert et al. 1982, Jacobsen et al. 1990). Timing of parturition is a complex process implying inflamatory (Behnia et al. 2015) and mechanical factors (Shynlova et al. 2013). According to the pregnancy clock theory, the coordination of several signals orchestrates the parturition triggers (Menon et al., 2016). Among these signals, fetal membrane senescence and more specifically the increase of telomere fragments in amniotic fluid near the term are supposed to be major initiators of the process of parturition (Polettini et al. 2015). This process is related to fetal maturation and ageing (Campisi et al., 2007), which in turn corresponds to a stage where growth process is achieved. This reveals a close relationship between gestational age and neonatal traits, and between neonatal traits and uterus height. All of these variables are related to the same process that fits the pregnancy clock adjustements, but this process is independent of pelvic traits. Among neonatal traits, suboccipito-bregmatic girth is not correlated with gestational age in multiple regression models. This exception could be explained in regard to the crucial role of the suboccipito-bregmatic girth in the course of delivery.

Bipedal locomotion has dramatically reshaped the pelvis. This locomotion is supposed to be the source of many humanlike pelvic patterns such as 1) the reduction of the sacro-cotyloid distance (between the sacro-iliac joints and the hip-joints) (Berge et al. 1984), 2) the angulation of $90^{\circ}$ between the inlet and outlet (Borell and Fernstrom, 1957b) (3) the anterior projection of the $1^{\text {st }}$ sacral vertebra (also called the promontory) (Abitbol, 1996). Human locomotor and obstetrical constraints seem to be contradictory (Krogman, 1951; Berge et al. 1984; Franciscus, 2009). The obstetric conjugate is the distance between the anterior part of the promontory and the upper and posterior part of the pubic symphysis. Yet, it also represents the antero-posterior dimension of the inlet. Therefore, this variable reflects the adjustement between obstetric and locomotor demands. In our work, obstetric conjugate is correlated to suboccipitobregmatic girth. This head perimeter represents the dimension of the head in the birth canal in case of well-flexed presentation. The flexion of the head is a necessary condition for a safe delivery since deflexed head could leads to relative cephalo-pelvic disproportion (Maharaj, 2010). Moreover, head flexion is crucial for the rotation of the head during its descent in the birth canal. Head flexion has the advantage of increasing the rotational momentum created by the strength of contractions on the presentation and the resulting reaction force of the anterior border of the pelvic brim (Malinas and Favier, 1979). Rotation of the head permits that fetal head and the maternal pelvic dimensions line up at all pelvic planes during the birth process (Rosenberg and Trevathan, 2002). Indeed, in humans the inlet is longer in the oblique dimensions whereas the midplane and the outlet are longer in the sagittal (antero-posterior) dimensions (Rosenberg and Trevathan, 2002; Maharaj, 2010). According to the 
obstetric dilemma hypothesis, rotational birth is an adaptation of the fetal head descent to the twisted shape of the birth canal that has been attributed to selection for increased biomechanical efficiency during bipedal locomotion (Rosenberg, 1992; Rosenberg andTrevathan, 1996; 2002; Franciscus, 2009; Trevathan, 2011). Rotational birth mechanism also appears because of the increase of neonatal head volume (Wittman and Wall, 2007) according to the increase of adult cranial capacity i.e. encephalization process, during the course of human evolution (DeSilva and Lesnik, 2008; DeSilva, 2011). Flexion of the head is a simple mechanism that minimizes the presenting crosssectional diameter of the head. Indeed, the suboccipitobregmatic diameter is c.a. 9,5 cm whereas the occipito-frontal diameter, corresponding to the neutral presentation, is c.a. $11.5 \mathrm{~cm}$ (Maharaj, 2010). The correlation between obstetric conjugate and suboccipito-bregmatic girth could be explained by the close fitting between bipedal demands and the conflicting increase of neonatal head volume occuring during human evolution. This unique correlation between a pelvic and a neonatal trait could be the signature of the obstetric dilemma.

\section{Conclusion}

Maternal height is associated with pelvic traits following the allometric relationships previously described by many authors (Holland et al., 1982; Ruff et al., 1997; Tague, 2000). Fetal growth is more sensitive to inflexible component of maternal phenotype (height) rather than external ecological conditions and nutritional status proxied by BMI. Fetal growth process and maturation are independent of pelvic traits. However, the relationship between neonatal and pelvic traits is not uniform among the dimensions of the neonate. The close fitting between obstetric conjugate and suboccipitobregmatic girth appears obstetrically efficient. This might be a signature of the adaptation of human parturition to alleviate the obstetric dilemma.

Orcid:

Pierre Frémondière: ID 0000-0003-2800-4217

Author Contributions: PF designed the study, collected and analyzed the data. PF, FM and LT drafted the manuscript.

Acknowledgments: This research was funded by the CNRS grants GDR 3592 and IRN Bipedal Equilibrium.

Conflict of Interest Statement: Authors declare no competing interests.

\section{References}

Abitbol, M.M. (1996). The shapes of the female pelvis: contributing factors. The Journal of Reproductive Medicine, 41, 242-250.

Betti, L., Cramon-Taubadel, N., Manica, A., \& Lycett, S.J. (2014). The interaction of neutral evolutionary processes with climatically driven adaptive changes in the 3D shape of the human os coxae. Journal of human evolution, 73, 64-74. 
Betti, L., \& Manica, A. (2018). Human variation in the shape of the birth canal is significant and geographically structured. Proceedings of the Royal Society B, 285, 1-9.

Behnia, F., Taylor, B.D., Woodson, M., Kacerovsky, M., Hawkins, H., Fortunato, S.J., Saade, G.R., \& Menon, R. (2015). Chorioamniotic Membrane Senescence: A Signal for Parturition? American Journal of Obstetrics and Gynecology, 213, e1-e16.

Berge, C., Orban-Segebarth, R., \& Schmid, P. (1984). Obstetrical interpretation of the australopithecine pelvic cavity. Journal of Human Evolution, 13, 573-587.

Bogin, B. (1997). Evolutionary hypotheses for human childhood. Yearbook of Physical Anthropology, 40, 63-89.

Borell, U., \& Fernström, I. (1957a). The movements at the sacro-iliac joints and their importance to changes in the pelvic dimensions during parturition. Acta Obstetricia et Gynecologica Scandinavica, 36, 42-57.

Borell, U., \& Fernström, I. (1957b). Shape and course of the birth canal. A radiographic study in the human. Acta Obstetrica et Gynecologica Scandinavica, 36, 166-178.

Calvert, JP., Crean, E.E., Newcombe, R.G., \& Pearson, J.F. (1982). Anternatal screening by measurement of symphysis-fundus height. British Medical Journal, 285, 846-849.

Campisi, J., \& d'Adda di Fagagna, F. (2007). Cellular senescence: when bad things happen to good cells. Nature Reviews Molecular Cell Biology, 8, 729-740.

Coqueugniot, H., \& Hublin, J.J. (2007). Endocranial Volume and Brain Growth in Immature Neandertals. Periodicum biologorum, 109, 379-385.

Ducarme, G., Seguro, E., Chesnoy, V., Davitian, C., \& Luton, D. (2012). Estimation of fetal weight by external abdominal measurements and fundal height measurement near term for the detection of intra-uterine growth retardation. Gynécologie Obstétrique \& Fertilité, 40, 642-646.

Dunsworth, H.M. (2018). There Is No "Obstetrical Dilemma" towards a braver medicine with fewer childbirth interventions. Perspectives in Biology and Medicine, 61, 249-263.

DeSilva, J. M., \& Lesnik, J.J. (2008). Brain size at birth throughout human evolution: A new method for estimating neonatal brain size in hominins. Journal of Human Evolution, 55, 1064-1074.

DeSilva, J. M. (2011). A shift toward birthing relatively large infants early in human evolution. Proceedings of the National Academy of Sciences of the United States of America, 108, 1022-1027.

Dunsworth, H.M., Warrener, A.G., Deaconc, T., Ellisonb, P.T., \& Pontzerd, H. (2012). Metabolic hypothesis for human altriciality. Proceedings of the National Academy of Sciences of the United States of America, 109, 15212-15216.

Ferguson, J.E., Newberry Y. G., DeAngelis, G.A., Finnerty, J.J., Agarwal, S., Turkheimer, E. (1998). The fetal-pelvic index has minimal utility in predicting fetalpelvic disproportion. American Journal of Obstetrics and Gynecology, 179, 1186-1192. 
Fournié, A., Lefebvre-Lacoeuille, C., Cotici, V., Harif, M., \& Descamps, P. (2007). The fundal height measurements in single pregnancies and the detection of fetal growth retardation. Journal de Gynécologie Obstétrique et Biologie de la Reproduction, 36, 625-630.

Franciscus, RG. (2009). When did the modern human pattern of childbirth arise? New insights from an old Neandertal pelvis. Proceedings of the National Academy of Sciences of the United States of America, 106, 9125-9126.

Frémondière, P., Thollon, L., \& Marchal, F. (2017). The emergence of obstetrical mechanism: From Lucy to Homo sapiens. Gynécologie Obstétrique Fertilité \& Sénologie, 45, 164-171.

Häusler, M., \& Schmid, P. (1995). Comparison of the Pelves of Sts-14 and AL-288-1. Implications for birth and sexual dimorphism in Australopithecines. Journal of Human Evolution, 29, 363-383.

Hinde, K., \& Milligan, L.A. (2011). Primate milk: proximate mechanisms and ultimate perspectives. Evolutionary Anthropology, 20, 9-23.

Holland, E.L., Cran, G.W., Elwood, J.H., Pinkerton, J.H.M., \& Thompson, W. (1982). Associations between pelvic anatomy, height and year of birth of men and women in Belfast. Annals of Human Biology, 9, 113-120.

Jacobsen, G., Johnsen, T.S., \& Knoff, T. (1990). Variability of symphysis-fundus height measurements: an experimental study among general practitioners. Scandinavian Journal of Primary Health Care, 8, 101-105.

Kramer, MS. (1987). Determinants of low birth weight: methodological assessment and metaanalysis. Bulletin of theWorld Health Organization, 65, 663-737.

Krogman, WM. (1951). The scars of human evolution. Scientific American, 184, 54-57.

Leutenegger, W. (1972). Newborn size and pelvic dimensions of Australopithecus. Nature, 240 , 568569.

Leutenegger, W. (1979). Monogamy in callitrichids: a Consequence of Phyletic Dwarfism? International Journal of Primatology, 1, 95-98.

Leutenegger, W. (1982). Encephalization and obstetrics in primate with particular reference to human evolution. In E. Armstrong, D. Falk (Eds.), Primate Brain Evolution: Methods and Concepts. (pp: 85-95). New York: Plenum Press.

Schaal, J.P., \& Riethmuller, D. (2007) Engagement. In J.P. Schaal, D. Riethmuller, R. Maillet, M. Uzan (Eds.), Mecanique \& Techniques Obstetricales. (3rd edn.) (pp: 245-258). Paris, France: Sauramps medical.

Liu, L., Bailey, S.M., Okuka, M., Munoz, P., Li, C., Zhou, L., Wu, C., Czerwiec, E., Sandler, L., Seyfang A Blasco, M.A. \& Keefe, D.L. (2007). Telomere lengthening early in development. Nature Cell Biology, 9, 1436-1441. 
Lovejoy, C. (2005). The natural history of human gait and posture Part 1. Spine and Pelvis. Gait and Posture, 21, 95-112.

Maharaj, D. (2010). Assessing cephalopelvic disproportion: back to the basics. Obstetrical \& Gynecological Survey, 65, 387-395.

Malinas, Y., \& Favier, M. (1979). ABC de mécanique obstétricale. Paris, Masson.

Martin, R.D. (2007). The evolution of human reproduction: a primatological perspective. Yearbook of physical anthropology, 50, 59-84.

Mahmood, T.A., Campbell, D.M., \& Wilson, A.W. (1988). Maternal height shoe size, and outcome of labor in white primigravidas: A prospective anthropometric study. British Medical Journal, 297, 20-7.

Menon, R., Bonney, E.A., Condon, J., Mesiano, S., \& Taylor, R.N. (2016). Novel concepts on pregnancy clocks and alarms: redundancy and synergy in human parturition. Human Reproduction Update, 22, 535-560.

Polettini, J., Behnia, F., Taylor, B.D., Saade, G.R., Taylor, R.N., \& Menon, R. (2015). Telomere fragment induced amnion cell senescence: a contributor to parturition? PLoS One, 10, e0137188.

Portmann, A. (1941). Die Tragzeiten der Primaten und die Dauer der Schwangerschaft beim Menschen: Ein Problem der vergleichenden Biologie. Revue Suisse de Zoologie, 48, 511-518.

Portmann, A. (1969). Biologische Fragmente zu einer Lehre vom Menschen. Basel, Schwabe.

Rosenberg, K. (1992). The evolution of modern childbirth. Yearbook of Physical Anthropology, 35, 89124.

Rosenberg, K., \& Trevathan, W. (1996). Bipedalism and human birth: the obstetrical dilemma. Evolutionary Anthropology, 4, 161-168.

Rosenberg, K., \& Trevathan, W. (2002). Birth, obstetrics and human evolution. BJOG: an International Journal of Obstetrics and Gynaecology, 109, 1199-1206.

Ruff, C.B., Trinkaus, E., \& Holliday, T.W. (1987). Body mass and encephalization in Pleistocene Homo. Nature, 387, 173-176.

Schaal, J.P., \& Riethmuller, D. (2007) Engagement. In J.P. Schaal, D. Riethmuller, R. Maillet, M. Uzan (Eds.), Mecanique \& Techniques Obstetricales. (3rd edn.) (pp: 245-258). Paris, France: Sauramps medical.

Schultz, AH. (1969). The life of primates. New York, Universe Books.

Shynlova, O., Lee, Y.H., Srikhajon, K., \& Lye, S.J. (2013). Physiologic uterine inflammation and labor onset: integration of endocrine and mechanical signals. Reproductive Sciences, 20, 154-167.

Tague, R., \& Lovejoy, C.O. (1986). The obstetric pelvis of A.L. 288-1 (Lucy). Journal of Human Evolution, 15, 237-255. 
Tague, R. (2000). Do big females have big pelves ? American Journal of Physical Anthropology, 112, 377-393

Trevathan, W.R. (2011). Human birth: an evolutionary perspective. New Brunswick, Aldine Transaction.

Walrath, D. (2003). Rethinking pelvic typologies and the human birth mechanism. Current anthropology, 44, 5-31.

Walsh, JA. (2008). Evolution and the cesarean section rate. The American Biology Teacher, 70, 401404.

Warrener

Washburn, SL. (1960). Tools and human evolution. Scientific American, 203, 63-75.

Weaver, TD., \& Hublin, JJ. (2009). Neandertal birth canal shape and the evolution of human childbirth. Proceedings of the National Academy of Sciences of the United States of America, 106, 8151-8156.

Wells, J.C.K. (2009). What was human birth weight in the past? Simulations based on data on stature from the palaeolithic to the present. Journal of Life Sciences, 1, 115-120

Wells, J.C.K., Figueiroa, J.N., \& Alves, J.G. (2017). Maternal pelvic dimensions and neonatal size. Evolution, Medicine, and Public Health, 1, 191-200.

Wittman, AB. \& Wall, LL. (2007). The evolutionary origins of obstructed labor: bipedalism, encephalization, and the human obstetric dilemma. Obstetrical \& Gynecological Survey, 62, 739-748.

Figure 1 Maternal and neonatal traits 


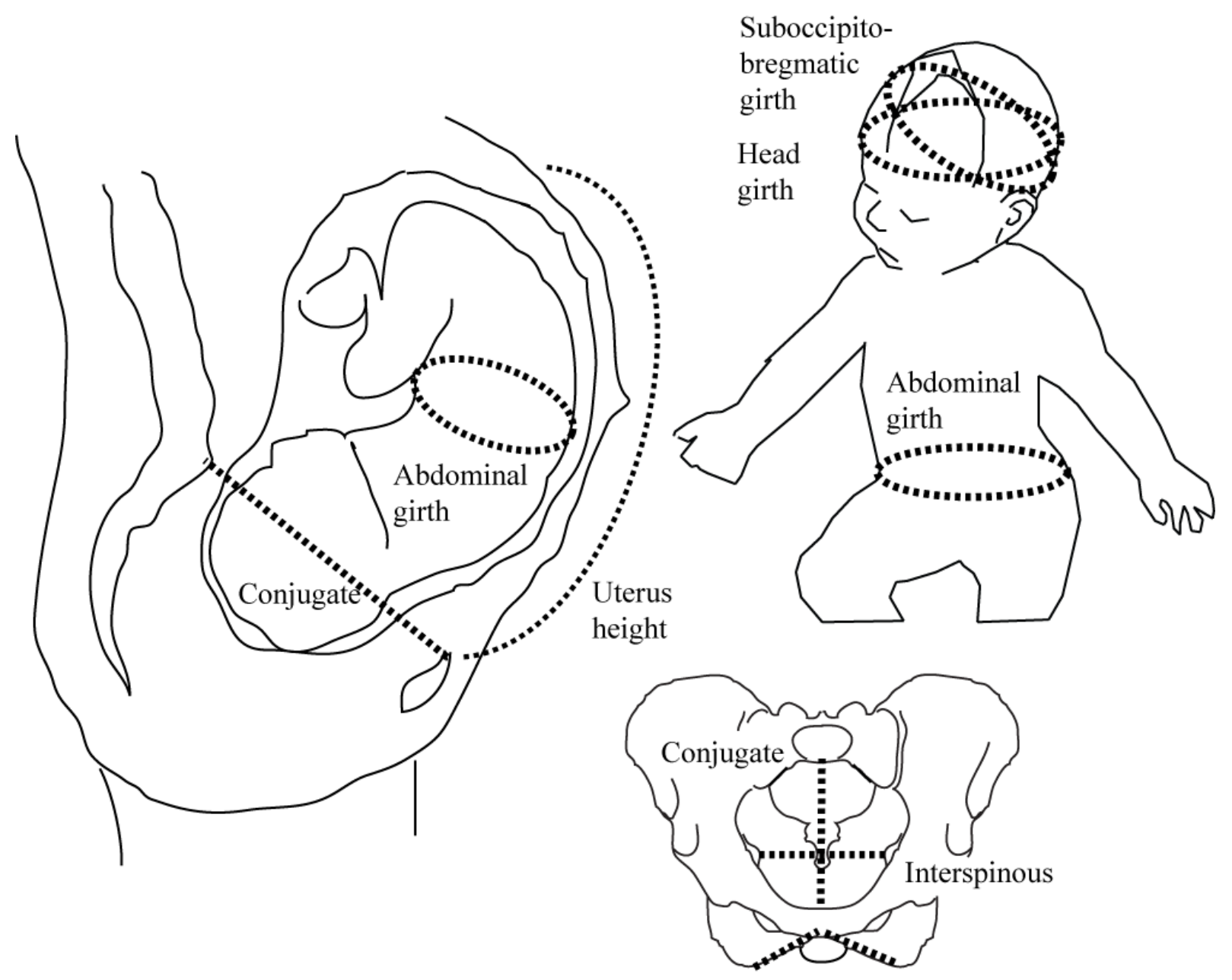

Subpubic angle

Table 1 Description of maternal and infant variables

\begin{tabular}{|l|l|l|l|}
\hline Trait & Mean & SD & Range \\
\hline Age $(\mathrm{y})$ & 31.9 & 4.5 & $22-42$ \\
\hline Weight $(\mathrm{kg})$ & 64.1 & 14.1 & $40-142$ \\
\hline Height $(\mathrm{cm})$ & 162.1 & 6.5 & $149-178$ \\
\hline BMI $\left(\mathrm{kg} / \mathrm{m}^{2}\right)$ & 24.2 & 5.8 & $17-49$ \\
\hline $\begin{array}{l}\text { Conjugate diameter } \\
\text { (mm) }\end{array}$ & 121.1 & 9.2 & $95-142$ \\
\hline $\begin{array}{l}\text { Interspinous diameter } \\
\text { (mm) }\end{array}$ & 105.7 & 8.1 & $84-134$ \\
\hline Subpubic angle $\left(^{\circ}\right)$ & 83.7 & 6.9 & $68-100$ \\
\hline Uterus height (cm) & 33.2 & 2.4 & $29-41$ \\
\hline $\begin{array}{l}\text { Neonate } \\
\text { Gestational age (wks) }\end{array}$ & 39.5 & 1.1 & $37-41$ \\
\hline Birth weight (g) & 3433.3 & 489.9 & $2300-4600$ \\
\hline Head girth (mm) & 348.4 & 11.4 & $317-376$ \\
\hline $\begin{array}{l}\text { Suboccipito-bregmatic } \\
\text { girth (mm) }\end{array}$ & 327.8 & 11.4 & $299-355$ \\
\hline Abdominal girth (mm) & 330.6 & 22.4 & $270-396$ \\
\hline
\end{tabular}

$\mathrm{SD}$, standard deviation 
Table 2. Correlations among maternal traits and neonatal size

\begin{tabular}{|c|c|c|c|c|c|c|c|c|c|}
\hline & \multicolumn{4}{|c|}{ Maternal trait } & \multicolumn{5}{|c|}{$\begin{array}{l}\text { Neonat trait } \\
\text { al }\end{array}$} \\
\hline & Conjugate & $\begin{array}{l}\text { Inter- } \\
\text { spinou } \\
\text { s }\end{array}$ & $\begin{array}{l}\text { Sub- } \\
\text { pubic } \\
\text { angle }\end{array}$ & $\begin{array}{l}\text { Uterus } \\
\text { height }\end{array}$ & $\begin{array}{l}\text { Gestat } \\
\text { ional } \\
\text { age }\end{array}$ & Weight & $\begin{array}{l}\text { Head } \\
\text { girth }\end{array}$ & $\begin{array}{l}\text { Suboccipito } \\
\text {-bregmatic } \\
\text { girth }\end{array}$ & $\begin{array}{l}\text { Abdominal } \\
\text { girth }\end{array}$ \\
\hline \multicolumn{10}{|l|}{$\begin{array}{l}\text { Maternal } \\
\text { trait }\end{array}$} \\
\hline Height & $0,424 * *$ & $\begin{array}{l}0,299 * \\
*\end{array}$ & $-0,047$ & $-0,030$ & 0,060 & $0,220^{*}$ & 0,133 & $0,202^{*}$ & $0,193^{*}$ \\
\hline BMI & $-0,101$ & 0,073 & $-0,006$ & $\begin{array}{l}0,387 * \\
*\end{array}$ & 0,003 & 0,106 & 0,120 & 0,029 & $-0,001$ \\
\hline Conjugate & & 0,079 & $-0,170$ & $-0,017$ & 0,059 & 0,128 & 0,125 & $0,235^{* *}$ & 0,132 \\
\hline $\begin{array}{l}\text { Inter- } \\
\text { spinous }\end{array}$ & & & $\begin{array}{l}0,591 * \\
*\end{array}$ & 0,086 & $-0,121$ & 0,127 & 0,101 & 0,085 & 0,146 \\
\hline $\begin{array}{l}\text { Subpubic } \\
\text { angle }\end{array}$ & & & & 0,052 & $-0,062$ & 0,091 & 0,002 & $-0,004$ & 0,058 \\
\hline $\begin{array}{l}\text { Uterus } \\
\text { height }\end{array}$ & & & & & 0,120 & $\begin{array}{l}0,527^{*} \\
*\end{array}$ & $\begin{array}{l}0,403^{*} \\
*\end{array}$ & $0,449 * *$ & $0,394 * *$ \\
\hline \multicolumn{10}{|l|}{$\begin{array}{l}\text { Neonatal } \\
\text { trait }\end{array}$} \\
\hline $\begin{array}{l}\text { Gestational } \\
\text { age }\end{array}$ & & & & & & $\begin{array}{l}0,358^{*} \\
*\end{array}$ & $\begin{array}{l}0,360 * \\
*\end{array}$ & $0,177^{*}$ & $0,287 * *$ \\
\hline Weight & & & & & & & $\begin{array}{l}0,655 * \\
*\end{array}$ & $0,645^{* *}$ & $0,768 * *$ \\
\hline Head girth & & & & & & & & $0,709 * *$ & $0,449 * *$ \\
\hline $\begin{array}{l}\text { Suboccipit } \\
\text { o- } \\
\text { bregmatic } \\
\text { girth }\end{array}$ & & & & & & & & & $0,447^{* *}$ \\
\hline
\end{tabular}

*. Correlation is significant at the 0.05 level. **. Correlation is significant at the 0.01 level. 
Table 3. Multiple regression models of offspring traits on maternal BMI, uterus height and pelvic traits.

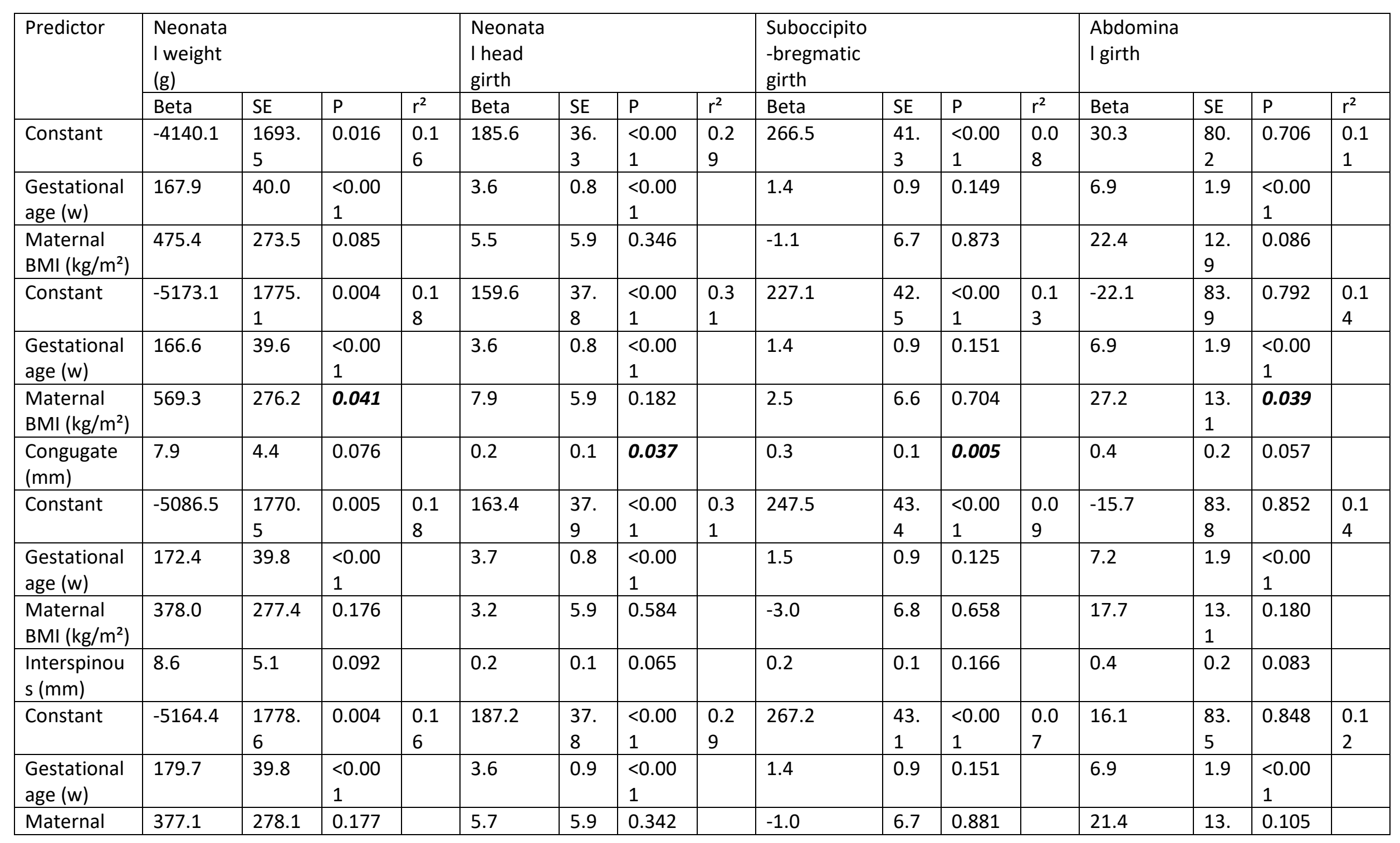




\begin{tabular}{|c|c|c|c|c|c|c|c|c|c|c|c|c|c|c|c|c|}
\hline $\mathrm{BMI}\left(\mathrm{kg} / \mathrm{m}^{2}\right)$ & & & & & & & & & & & & & & 1 & & \\
\hline $\begin{array}{l}\text { Subpubic } \\
\text { angle }\left({ }^{\circ}\right)\end{array}$ & 0.3 & 7.1 & 0.966 & & -0.2 & 0.1 & 0.872 & & -0.1 & 0.1 & 0.950 & & 0.2 & 0.3 & 0.524 & \\
\hline Constant & -5807.4 & $\begin{array}{l}1490 . \\
1 \\
\end{array}$ & $\begin{array}{l}<0.00 \\
1 \\
\end{array}$ & $\begin{array}{l}0.3 \\
9 \\
\end{array}$ & 155.3 & $\begin{array}{l}33 . \\
9\end{array}$ & $\begin{array}{l}<0.00 \\
1 \\
\end{array}$ & $\begin{array}{l}0.4 \\
2 \\
\end{array}$ & 227.7 & $\begin{array}{l}37 . \\
2 \\
\end{array}$ & $\begin{array}{l}<0.00 \\
1 \\
\end{array}$ & $\begin{array}{l}0.2 \\
9 \\
\end{array}$ & -15.2 & $\begin{array}{l}76 . \\
8 \\
\end{array}$ & 0.844 & $\begin{array}{l}0.2 \\
3 \\
\end{array}$ \\
\hline $\begin{array}{l}\text { Gestational } \\
\text { age (w) }\end{array}$ & 134.6 & 35.2 & $\begin{array}{l}<0.00 \\
1 \\
\end{array}$ & & 3.1 & 0.8 & $\begin{array}{l}<0.00 \\
1 \\
\end{array}$ & & 0.7 & 0.9 & 0.419 & & 5.6 & 1.8 & 0.002 & \\
\hline $\begin{array}{l}\text { Maternal } \\
\text { BMI }\left(\mathrm{kg} / \mathrm{m}^{2}\right)\end{array}$ & -147.0 & 253.6 & 0.563 & & -5.2 & 5.7 & 0.369 & & -15.0 & 6.3 & 0.019 & & 2.7 & $\begin{array}{l}13 . \\
1\end{array}$ & 0.837 & \\
\hline $\begin{array}{l}\text { Uterus } \\
\text { height }(\mathrm{cm})\end{array}$ & 109.6 & 16.3 & $\begin{array}{l}<0.00 \\
1 \\
\end{array}$ & & 1.9 & 0.4 & $\begin{array}{l}<0.00 \\
1\end{array}$ & & 2.4 & 0.4 & $\begin{array}{l}<0.00 \\
1\end{array}$ & & 3.5 & 0.8 & $\begin{array}{l}<0.00 \\
1\end{array}$ & \\
\hline Constant & -7225.9 & $\begin{array}{l}1626 . \\
8 \\
\end{array}$ & $\begin{array}{l}<0.00 \\
1 \\
\end{array}$ & $\begin{array}{l}0.4 \\
1 \\
\end{array}$ & 129.0 & $\begin{array}{l}36 . \\
6\end{array}$ & 0.001 & $\begin{array}{l}0.4 \\
5 \\
\end{array}$ & 190.7 & $\begin{array}{l}40 . \\
1 \\
\end{array}$ & $\begin{array}{l}<0.00 \\
1 \\
\end{array}$ & $\begin{array}{l}0.3 \\
3 \\
\end{array}$ & -92.7 & $\begin{array}{l}83 . \\
3 \\
\end{array}$ & 0.268 & $\begin{array}{l}0.2 \\
7 \\
\end{array}$ \\
\hline $\begin{array}{l}\text { Gestational } \\
\text { age (w) }\end{array}$ & 135.3 & 35.0 & $\begin{array}{l}<0.00 \\
1 \\
\end{array}$ & & 3.1 & 0.8 & $\begin{array}{l}<0.00 \\
1 \\
\end{array}$ & & 0.7 & 0.9 & 0.415 & & 5.7 & 1.8 & 0.002 & \\
\hline $\begin{array}{l}\text { Maternal } \\
\mathrm{BMI}\left(\mathrm{kg} / \mathrm{m}^{2}\right)\end{array}$ & -138.2 & 262.7 & 0.6 & & -4.9 & 5.9 & 0.404 & & -12.9 & 6.5 & 0.048 & & 2.2 & $\begin{array}{l}13 . \\
4 \\
\end{array}$ & 0.867 & \\
\hline $\begin{array}{l}\text { Conjugate } \\
(\mathrm{mm})\end{array}$ & 5.7 & 4.0 & 0.155 & & 0.1 & 0.1 & 0.150 & & 0.2 & $\begin{array}{l}0.0 \\
1 \\
\end{array}$ & 0.021 & & 0.3 & 0.2 & 0.154 & \\
\hline $\begin{array}{l}\text { Interspinou } \\
\mathrm{s}(\mathrm{mm})\end{array}$ & 5.6 & 5.8 & 0.336 & & 0.2 & 0.1 & 0.064 & & 0.1 & 0.1 & 0.311 & & 0.5 & 0.3 & 0.123 & \\
\hline $\begin{array}{l}\text { Subpubic } \\
\text { angle }\left({ }^{\circ}\right)\end{array}$ & 2.3 & 6.4 & 0.724 & & -0.2 & 0.1 & 0.231 & & -0.1 & 0.1 & 0.649 & & -0.1 & 0.3 & 0.901 & \\
\hline $\begin{array}{l}\text { Uterus } \\
\text { height }(\mathrm{cm})\end{array}$ & 107.2 & 16.3 & $\begin{array}{l}<0.00 \\
1\end{array}$ & & 1.8 & 0.4 & $\begin{array}{l}<0.00 \\
1\end{array}$ & & 2.4 & 0.4 & $\begin{array}{l}<0.00 \\
1\end{array}$ & & 3.4 & 0.8 & $\begin{array}{l}<0.00 \\
1\end{array}$ & \\
\hline
\end{tabular}

Bold indicates predictors other than constant that are significant $\mathrm{P}<0.05$.

Beta, untransformed B-coefficient; SE, standard error of B-coefficient.

Maternal BMI natural log-transformed.

All models adjusted for birth order and infant sex, by including (when significant $\mathrm{P}<0.1$ ) dummy variables for second-born and infant sex. 
Table 4. Multiple regression models of neonatal weight on maternal height, uterus height and pelvic dimensions

\begin{tabular}{|c|c|c|c|c|c|c|c|c|}
\hline Predictor & \multicolumn{8}{|c|}{$\begin{array}{l}\text { Neonatal } \\
\text { weight }(\mathrm{g})\end{array}$} \\
\hline Constant & -5791.8 & 1776.7 & 0.001 & 0.20 & -10051.1 & 1532.9 & $<0.001$ & 0.48 \\
\hline $\begin{array}{l}\text { Maternal } \\
\text { height }(\mathrm{cm})\end{array}$ & 16.1 & 6.1 & 0.01 & & 8.0 & 5.1 & 0.116 & \\
\hline $\begin{array}{l}\text { Neonatal head } \\
\text { girth }(\mathrm{mm})\end{array}$ & & & & & 27.5 & 3.4 & $<0.001$ & \\
\hline $\begin{array}{l}\text { Gestational } \\
\text { age }(w)\end{array}$ & 160.7 & 39.1 & $<0.001$ & & 68.1 & 33.8 & 0.046 & \\
\hline $\begin{array}{l}\text { Maternal } \\
\text { height }(\mathrm{cm})\end{array}$ & 14.1 & 6.8 & 0.039 & & 7.9 & 5.5 & 0.153 & \\
\hline $\begin{array}{l}\text { Conjugate } \\
(\mathrm{mm})\end{array}$ & 3.3 & 4.8 & 0.494 & & 0.1 & 3.9 & 0.985 & \\
\hline $\begin{array}{l}\text { Maternal } \\
\text { height }(\mathrm{cm})\end{array}$ & 13.9 & 6.4 & 0.031 & & 7.5 & 5.3 & 0.155 & \\
\hline $\begin{array}{l}\text { Interspinous } \\
(\mathrm{mm})\end{array}$ & 5.7 & 5.2 & 0.277 & & 1.3 & 4.3 & 0.755 & \\
\hline $\begin{array}{l}\text { Neonatal head } \\
\text { girth }(\mathrm{mm})\end{array}$ & & & & & 27.3 & 3.4 & $<0.001$ & \\
\hline Constant & -6402.9 & 1859.6 & 0.001 & 0.21 & -10646.4 & 591.8 & $<0.001$ & 0.49 \\
\hline $\begin{array}{l}\text { Gestational } \\
\text { age (w) }\end{array}$ & 161.4 & 39.0 & $<0.001$ & & 68.9 & 33.5 & 0.042 & \\
\hline
\end{tabular}




\begin{tabular}{|c|c|c|c|c|c|c|c|c|}
\hline $\begin{array}{l}\text { Maternal } \\
\text { height }(\mathrm{cm})\end{array}$ & 16.4 & 6.1 & 0.008 & & 8.4 & 5.1 & 0.100 & \\
\hline $\begin{array}{l}\text { Subpubic } \\
\text { angle (mm) }\end{array}$ & 6.3 & 5.7 & 0.272 & & 6.2 & 4.6 & 0.184 & \\
\hline $\begin{array}{l}\text { Neonatal head } \\
\text { girth }(\mathrm{mm})\end{array}$ & & & & & 27.4 & 3.4 & $<0.001$ & \\
\hline Constant & -8327.8 & 1548.8 & $<0.001$ & 0.44 & -10582.1 & 1421.2 & $<0.001$ & 0.56 \\
\hline $\begin{array}{l}\text { Gestational } \\
\text { age (w) }\end{array}$ & 128.2 & 33.7 & $<0.001$ & & 69.4 & 31.4 & 0.029 & \\
\hline $\begin{array}{l}\text { Maternal } \\
\text { height }(\mathrm{cm})\end{array}$ & 16.5 & 5.3 & 0.002 & & 10.1 & 4.8 & 0.036 & \\
\hline $\begin{array}{l}\text { Uterus height } \\
(\mathrm{cm})\end{array}$ & 106.8 & 14.8 & $<0.001$ & & 70.2 & 14.5 & $<0.001$ & \\
\hline $\begin{array}{l}\text { Neonatal head } \\
\text { girth }(\mathrm{mm})\end{array}$ & & & & & 20.5 & 3.5 & $<0.001$ & \\
\hline
\end{tabular}

Bold indicates predictors other than constant that are significant $\mathrm{P}<0.05$.

Beta, untransformed B-coefficient; SE, standard error of B-coefficient.

Maternal BMI natural log-transformed.

All models adjusted for birth order and infant sex, by including (when significant $\mathrm{P}<0.1$ ) dummy variables for second-born and infant sex. 
Annexe

Table: Comparaison of p-values of multiple regression models between our study and Wells et al. (2017)

\begin{tabular}{|c|c|c|c|c|}
\hline \multirow[t]{2}{*}{ Predictor } & \multicolumn{2}{|c|}{$\begin{array}{l}\text { Neonatal } \\
\text { weight }(\mathrm{g})\end{array}$} & \multicolumn{2}{|l|}{$\begin{array}{l}\text { Neonatal head } \\
\text { girth }\end{array}$} \\
\hline & $\begin{array}{l}\mathrm{P} \text { (our } \\
\text { study) }\end{array}$ & $\begin{array}{l}\text { P (wells et al } \\
2017)\end{array}$ & P (our study) & P (wells et al 2017) \\
\hline Constant & 0.016 & $<0.0001$ & $<0.001$ & $<0.0001$ \\
\hline $\begin{array}{l}\text { Gestational } \\
\text { age (w) }\end{array}$ & $<0.001$ & $<0.0001$ & $<0.001$ & $<0.0001$ \\
\hline $\begin{array}{l}\text { Maternal } \\
\text { BMI }\left(\mathrm{kg} / \mathrm{m}^{2}\right)\end{array}$ & 0.085 & 0.012 & 0.346 & 0.3 \\
\hline Constant & 0.004 & $<0.0001$ & $<0.001$ & $<0.0001$ \\
\hline $\begin{array}{l}\text { Gestational } \\
\text { age }(w)\end{array}$ & $<0.001$ & $<0.0001$ & $<0.001$ & $<0.0001$ \\
\hline $\begin{array}{l}\text { Maternal } \\
\mathrm{BMI}\left(\mathrm{kg} / \mathrm{m}^{2}\right)\end{array}$ & 0.041 & 0.6 & 0.182 & 0.4 \\
\hline $\begin{array}{l}\text { Congugate } \\
(\mathrm{mm})\end{array}$ & 0.076 & 0.004 & 0.037 & 0.009 \\
\hline Constant & 0.005 & 0.002 & $<0.001$ & $<0.0001$ \\
\hline $\begin{array}{l}\text { Gestational } \\
\text { age }(w)\end{array}$ & $<0.001$ & $<0.0001$ & $<0.001$ & $<0.0001$ \\
\hline $\begin{array}{l}\text { Maternal } \\
\mathrm{BMI}\left(\mathrm{kg} / \mathrm{m}^{2}\right)\end{array}$ & 0.176 & 0.6 & 0.584 & 0.5 \\
\hline $\begin{array}{l}\text { Interspinous } \\
(\mathrm{mm})\end{array}$ & 0.092 & $<0.0001$ & 0.065 & 0.003 \\
\hline Constant & 0.004 & 0.012 & $<0.001$ & - \\
\hline $\begin{array}{l}\text { Gestational } \\
\text { age }(w)\end{array}$ & $<0.001$ & - & $<0.001$ & - \\
\hline $\begin{array}{l}\text { Maternal } \\
\mathrm{BMI}\left(\mathrm{kg} / \mathrm{m}^{2}\right)\end{array}$ & 0.177 & - & 0.342 & - \\
\hline Subpubic & 0.966 & - & 0.872 & - \\
\hline
\end{tabular}




\begin{tabular}{|l|l|l|l|l|}
\hline angle $\left(^{\circ}\right)$ & & & & \\
\hline Constant & $<0.001$ & - & $<0.001$ & - \\
\hline $\begin{array}{l}\text { Gestational } \\
\text { age }(\mathrm{w})\end{array}$ & $<0.001$ & - & $<0.001$ & - \\
\hline $\begin{array}{l}\text { Maternal } \\
\text { BMI }\left(\mathrm{kg} / \mathrm{m}^{2}\right)\end{array}$ & 0.563 & - & 0.369 & - \\
\hline $\begin{array}{l}\text { Uterus } \\
\text { height }(\mathrm{cm})\end{array}$ & $<0.001$ & - & $<0.001$ & - \\
\hline Constant & $<0.001$ & 0.028 & 0.001 & $<0.0001$ \\
\hline $\begin{array}{l}\text { Gestational } \\
\text { age (w) }\end{array}$ & $<0.001$ & $<0.0001$ & $<0.001$ & $<0.0001$ \\
\hline $\begin{array}{l}\text { Maternal } \\
\text { BMI (kg/m }{ }^{2} \text { ) }\end{array}$ & 0.6 & 0.18 & 0.404 & 0.2 \\
\hline $\begin{array}{l}\text { Conjugate } \\
\text { (mm) }\end{array}$ & 0.155 & 0.6 & 0.150 & 0.2 \\
\hline $\begin{array}{l}\text { Interspinous } \\
\text { (mm) }\end{array}$ & 0.336 & 0.006 & 0.064 & 0.079 \\
\hline $\begin{array}{l}\text { Subpubic } \\
\text { angle }\left(^{\circ}\right)\end{array}$ & 0.724 & - & 0.231 & - \\
\hline $\begin{array}{l}\text { Uterus } \\
\text { height (cm) }\end{array}$ & $<0.001$ & - & $<0.001$ & - \\
\hline
\end{tabular}

